\title{
A Reflection on Academisation and its Effect on Curriculum Transformation in South Africa's Higher Education Sector
}

\author{
Primrose T. Sabela \\ ORCID iD: https://orcid.org/0000-0002-7189-9194
}

Mfundo Mandla Masuku

ORCID iD: https://orcid.org/0000-0003-3743-0779

Lindelani Q. Qwabe

ORCID iD: $\underline{\text { https://orcid.org/000-0003-2266-2104 }}$

\begin{abstract}
South Africa's higher education has undergone complex processes of state mandated institutional restructuring since the demise of apartheid. These have resulted in an increase in access to higher education and several processes of regulating the administration, organisation, management, and functioning of the country's institutions of higher learning. The transformation of higher education in South Africa has relied on, among other factors, discourses of academisation to address historical legacies of inequity, and transform the country's higher education curriculum. In this paper, we explore how the discourse of academisation has changed the country's vocational programmes from being alternatives to university studies to becoming universities of technology. This change has compelled vocational programmes to shift their focus and re-curriculate thus interfering with staff composition and constraining rather than creating an autonomous atmosphere for actual curriculum transformation and implementation. The country's higher education sector needs to reflect critically on its current process of curricular transformation by interrogating if and how these transformations respond to the needs of the
\end{abstract}


sector's stakeholders, namely students and their prospective employers. This critical reflection seeks to answer questions that focus on how the curriculum strives to include its stakeholders' narratives to help students to become socially responsive citizens, equipped with well-developed critical thinking skills. It is proposed that a participatory platform be established to which all relevant stakeholders could contribute by helping to build an effective academic agenda. This could enable the country's higher learning institutions to be responsive to the rapidly changing needs and demands of employers by producing graduates who are both innovative and competitive critical thinkers.

Keywords: curriculum, transformation, academisation, responsiveness, higher education

\section{Introduction}

In the past, universities were associated with elitism, exclusion, and inequality. However, today's institutions are described as being diversified, globalised, borderless, marketised, neo-liberalised, and technologised (Hey \& Morley 2011). Further, these authors raise concerns about what the future holds for universities and whether current policy discourses enhance or limit creativity and critical thinking. Altbach and Davis (1999) recognise that profound transformations have taken place in higher education globally, and predict several challenges associated with the implications of these changes. Predicted about four decades ago, as these scholars remind us, these challenges have become cause for concern and much has been written about them. These include an increase in the number of students enrolled in higher education, diversity and demographic changes, the impact of new technologies, reconsiderations of the social and economic role of higher education, and others. Higher education expands with growing demand for graduate knowledge, skills, and certified professsional competencies (Adetiba 2019). However, expansion of the higher education sector has led to the production of unemployable graduates. Despite these challenges, few studies with a focus on the curriculum, pedagogical practices and approaches, and the consequential effects and impacts on the product produced - the sector's graduates - have been conducted.

Both traditional higher education institutions (HEIs) and universities of technology have been affected by either the global environment or circumstances within and beyond their borders (Altbach 2004). Such impacts 


\section{Primrose T. Sabela, Mfundo Mandla Masuku \& Lindelani Q. Qwabe}

are felt by universities located in countries that were never colonised. Although colonisation may not have impacted these nations, most universities in the Global South have copied and adopted foreign models of higher education, thus implementing their programme structures, curricula, course credit systems, management systems and so on. The implications of adopting without adapting foreign higher education structures, academic programmes, and policies must be examined in terms of how relevant or irrelevant these structures are. This leads to questions:

1. Whose standards are considered in curriculum, programme and policy development in higher education?

2. Who dictates the standards adopted in higher education?

3. Who determines the standards adopted in HEIs and on what basis?

4. What are the implications of transformation in higher education in terms of curriculum changes?

Exploring these critical issues can result in questions arising as to whether current higher education policies and curricula respond to local and global trends that manifest in prevalent conditions in the countries in which the institutions are located. According to Maassen and Cloete (2006), countries must consider reorienting and repositioning higher education systems if they are be responsive to the planetary changes. Further, universities continue to serve critical institutions that produce a well-trained, and informed workforce characterised by a critical and inquiring intellect.

In this paper, we reflect critically on the implications of academisation discourse on curriculum transformation in South Africa's higher education sector. We examine how the discourse of academisation has been applied to the curriculum of vocational programmes in the transformation of former technikons into universities of technology. In examining this kind of transformation, we focus on its broader implications. We seek to unpack critical questions that relate to whose interests are served by transforming the country's higher education sector and how responsive this transformed curriculum is to the needs of the country in terms of producing employable, informed, critical citizens.

One of the objectives of South Africa's former technikon system was to prepare students to be efficient and better qualified practitioners. Kreber (2006) maintains that the challenge in higher education has always been to 
prepare students who are not only discipline specialists and doers, but independent thinkers, productive citizens, and future leaders. Cranton (2011) observes a global trend that compels universities and colleges funded by the state to demonstrate how effective teaching is realised, which sometimes forces them to focus on the numbers produced (end-product) and the state subsidy to be obtained thereafter. We begin by conceptualising academisation in higher education, and this is followed by a history of higher education institutional transformation with a focus on the complexity of processes involved in the state's endeavour to restructure institutions of higher learning. Further, we also consider the landscape of the South African higher education system during the period before and after 1994. A prominent feature of the post 1994 phase is the democratisation of higher education largely informed by the democratic government. In the last section of the paper, we focus on the implications for the changed curriculum and structure of the higher education system and research in universities of technology.

\section{Conceptualisation of Academisation in Higher Education}

Despite that academisation has proven to be one of the most important trends witnessed in contemporary higher education, it has received comparatively limited attention in the field of higher education research as Ek et al. (2013) note. The concept is viewed against the backdrop of several changes in higher education after 1994. In this paper, our explanation of academisation is based on the transformation undergone by vocational programmes from being alternatives to universities, to becoming an integral part of higher education. This process has prompted former technikons to review, revise, and change their curricula from being purely practice-based to being theory-based. Unpacking the concept of higher education is essential since it forms the basis of understanding academisation and its effects on curriculum transformation. Higher education is conceived of as a contested concept with no precise definition. Barnett (1990) has raised questions about whether higher education is a single, albeit contested concept or a number of different concepts with little, if anything, in common or whether it is a concept which is used in distinct language games that are representative of rival ideologies. Scott (2019) explains an ideal model of higher education in terms of transition from elite to mass and then mass to universal higher education, arguing that variance in higher education institutions and the context defines higher education itself. 
Ambiguity in the definition of higher education is attributed to the plethora of dynamic challenges it faces that include internationalisation, academisation, marketisation, and massification. Further, the ambiguity and lack of consensus is exacerbated by continued demand for universities to be responsive to societal needs. The term higher education indicates postsecondary school education that covers a wide variety of institutions. In the South African context, the diversity of tertiary level institutions includes universities, former technikons, various types of colleges and others (Raju 2004). In addition, a higher education system is expected to provide transformative education and enable participatory parity irrespective of the type of institution. This includes the provision of education that shapes and prepares students for their respective life possibilities.

The concept of university is considered a key component of higher education. Lategan (2009) argues that there is neither a fixed structural understanding of what a university is, nor a one-size-fits-all approach. Importantly, universities are expected to prepare students to be the future workforce and not act only as knowledge-sharing institutions (McEwen \& Trede 2014). Thus, universities are also viewed as higher education institutions that equip students with knowledge that will allow them to participate in the field of power. According to Lategan (2008), traditional universities have three core functions: teaching and learning; research; and community engagement. These functions remain unchanged, yet they have taken a new direction in terms of commercialisation, innovations, and other changes. Further, comparing the functions of a traditional university with the core activities of universities of technology remains a mammoth task. It can be argued that the term university suggests that the three core functions apply to the universities of technology. Higher education should provide technical performance and knowledge production skills. Graduates must be equipped with high level critical thinking as well as analytical and creative conceptualisation skills (Ahrari et al. 2016). However, concerns have been raised about changes in higher education that involve institutions being merged and treated as a single system. A typical example is the change from technikons to universities of technology, calling for re-orientation of disciplines, programmes, and the curriculum, with important implications for co-operation and articulation among different types of higher education institutions. However, various influences have shaped the higher education system in Africa that include colonialism, apartheid, racialism, acculturation, and inequitable economic de- 
velopment (Ndlovu-Gatsheni 2017).

Many scholars have posited that higher education enhances scientific expertise while at the same time responding to items which should inform the curriculum such as market pressures and societal demands (Aina 2010; Barnett 1990; Lategan 2009). Thus, higher education institutions play multiple and sometimes contradictory roles as Brennan et al. (2004) point out; questions about policy issues in higher education, specifically whether the policies enhance or impede performance of the designated roles, are almost inevitable. Often, questions are raised in the context of productiveness, responsiveness, relevance, and transformative higher educational institutions. They include the identity of recipients of higher education, the output (what recipients obtain from HEIs and the future prospects of their graduates). Kyvik (2009) defines academisation as an educational discourse that has significantly changed the higher education fraternity. It refers to the intellectualisation of the higher education system in which various levels of change are discernible. The levels are identified as the policy drift that is used to describe governance issues, institutional drift to explain changes at the programme level, and academic drift to explain academisation processes that occur at student and staff levels (Kyvik 2009). Further, these levels are closely intertwined, but they become much easier to understand in terms of the dynamics and implications of academisation when the focus is directed at each individual level. Academisation is used to analyse a particular change that occurred in the South African higher education context that involved orienting activities in ways that bring technical education close to the university image, resulting in reconfiguration of the mission and functions of these institutions of higher learning.

Academisation is characterised by incorporating stronger elements of theory and engagement in knowledge production and dissemination. The definition of university provokes critical thinking which raises several questions such as whether providing this theory-flavoured curriculum adds any value that makes universities of technology produce different and more informed, productive, and relevant graduates. Further, exploring how reorienting the curriculum responds to market pressures and societal demands is worthwhile. Kyvik (2009) describes academisation as a functional response to the need for more theory in the curriculum with a belief that it contributes to better trained students who have the ability to cope with the demands of an increasingly knowledge-based labour market. This relates to curricular-drift that is characterised by accentuation of abstract knowledge, gradual reduction 
in emphasis attached to practical work, and a move away from a utilitarian approach in course curricula (Kyvik 2009).

According to Ek et al. (2013), academisation has several demands for engagement in knowledge production, and it compels vocational programmes to change focus towards a more active involvement in theory and research. Others argue that academisation could be somehow counterproductive for the maintenance of a diversified post-secondary higher education system since it may fail to respond to production of skilled labour for the practical profession vocations (Kyvik 2009). However, some authors claim that converting technikons to universities of technology has been confined to name changes alone and did not ever translate to any other significant alterations (Raju 2004; McKenna 2009). A focus on the historical developments in the higher education sector sheds light on the direct and indirect effects of academisation on curriculum transformation.

\section{An Overview of the South African Higher Education Sector}

The higher education sector in South Africa has undergone a series of changes to address legitimate concerns of inequity and redress, and to pursue the goals of increased access and success in higher education. McKenna (2009) maintains that a significant change to higher education in South Africa was aimed at creating a single unified public higher education sector. This aim resulted in merging many public HEIs and led to the creation of three types of institution - traditional universities, comprehensive universities, and universities of technology (McKenna 2009). Attention has been directed to addressing issues of inequality, historical legacies, and widened access with a minimum amount being paid to the discourses of change that influence curricular transformation. Badat (2010) posits that South Africa's higher education system has been profoundly shaped by apartheid planning and the socio-economic and political priorities of apartheid policies. Changes in South Africa's higher education have been driven by developments in the global context that include national conditions and needs (Dison et al. 2008). During the apartheid era (1948 to 1994), higher education was a complex and discriminatory system that boasted 21 universities, 15 technikons and a variety of colleges for the fields of education, agriculture, and nursing. Raju (2004) argues that the apartheid era was marked by initial tight state control of higher education and this changed to a brief period (in the mid-1980s) of de-regulated so-called free-market 
higher education. However, from 1994, higher education has been highly regulated again in the name of ensuring a more equitable, integrated, and efficient system (Habib et al. 2008; Raju 2004; Scott 2019). This has once again jeopardised the institutional autonomy and academic freedom of HEIs.

Through the Advanced Technical Education Act 40 of 1967, South Africa created advanced technical education systems with the aim of producing skilled and high-level personnel to meet the needs of both commerce and industry. The system was regarded as intermediate between matric and university and located in the higher education sector. Later, the Advanced Technical Education Amendment Act 43 of 1979 changed the name of the institutions to technikons. This change in name sought to ensure that technikons enjoyed free vertical development but with a difference in focus. These technikons were defined as HEIs of learning whose main responsibility was to provide education and training to supply the labour market with middleto-high level personnel, and they developed their unique qualifications parallel to universities. Post 1994, the Higher Education Act 101 of 1997 reaffirmed the autonomy of technikons within the higher education system although the Act seemed to be silent about the status of technikons and their relation to universities. Raju (2004) argues that institutions may be developed parallel to one another yet perform different functions and have different foci. Lategan (2008) perceives a university of technology as a unique institution but similar to the traditional universities. Furthermore, Universities of Technology must perform all the core functions of universities but not in the same way as the traditional type of university and should not lose focus on the target population served. The period after 1994 is characterised by the enactment of various legislative frameworks, courtesy of the democratic government that sought to address the injustices perpetrated by the previous regime. The plethora of legislative frameworks sought to ensure equal access to higher education. Further, they also aimed to regulate the administration, organisation, management, and the overall functioning of higher education institutions in South Africa. Section 16 (1) (d) of the Constitution of the Republic of South Africa is regarded as a constitutional recognition of the unique position of universities in democratic societies. It guarantees academic freedom as a constitutional right that alludes to the right to freedom of expression, which includes freedom of scientific research. It also recognises the academic freedom of lecturers, and the institutional autonomy of universities.

Further, the government of South Africa enacted policies such as the 
document on the Transformation and Restructuring: A New Institutional Landscape for Higher Education Institutions in South Africa, Higher Education Act101 of 1997, Education White Paper 3 of 1997 and the National Qualifications Framework Act 67 of 2008 (NQF) including the National Plan for Higher Education. Most of the regulatory frameworks have tended to constrain rather than liberate or create an autonomous atmosphere or lead to academic freedom within the higher education sector. Waghid et al. (2005) argue that the state has to a large extent instituted regulatory measures with regard to what gets taught and how, who teaches, and who is taught. The NQF, a framework that sets the boundaries, principles, and guidelines that provide a philosophical base and an organisational structure for the construction of a qualification system makes provision for the Minister of Higher Education and Training to have the overall responsibility for the NQF and determine the qualifications structure for the higher education system. However, the South African Qualifications Authority (SAQA), regulated in terms of the NQF Act, is responsible for the development of policy and criteria for registering standards and qualifications on the NQF upon recommendation by the Council for Higher Education (CHE). CHE is responsible for advising the Minister on matters related to higher education in South Africa. It also develops and manages the Higher Education Qualifications Sub-Framework (HEQSF), which forms an integral part of the NQF. The HEQSF is, in turn, responsible for establishing parameters and criteria for qualifications design and facilitates the comparability of qualifications across the higher education system (Revised HEQSF 2013).

The Education White Paper 3 of 1997, a Programme for Higher Education Transformation, outlines the framework for change in the South African higher education sector to ensure uniformity in how the system is planned, funded, and governed. According to Badat (2010), the discourse on transformation in higher education has revolved around issues of increased access and success, including improved participation and advancement of social equity. Further, the discourse on transformation has a thrust towards meeting the country's economic and social development needs, redressing past discrimination, and contributing to knowledge production to keep pace with international standards. The main focus of the Education White Paper 3 was to create a unified and coordinated national higher education system to overcome the fragmentation, inequality, and inefficiency of the higher education system. This unification intended to create a learning environment that promotes 
creativity and develops individuals with inquiring and critical intellectual abilities and aptitudes. The Education White Paper 3 of 1997 has also focused on addressing the needs of society in a knowledge-driven and knowledge-dependent manner for both the growth and prosperity of a modern economy. It is acknowledged in the policy that the country has a dual higher education system characterised by institutions that can claim academic achievement of international standard that co-exist with those parts of the system that observe teaching and research, and that favour academic insularity and closed-system disciplinary programmes (Aina 2010). Furthermore, transformation is possible and achievable, but requires understanding of the politics of the process of change. Badat (2010) notes that the Higher Education Act of 1997 and Education White Paper 3 declared the need to create a single coordinated higher education system but maintain diversity in the organisational structure of the institutional landscape. However, some of the Acts acknowledged in this paper, including the National Qualifications Framework Act (Act 67 of 2008) and the National Qualifications Sub-Framework of 2013 seem to be silent about the relationship between traditional universities and Universities of Technology.

\section{Implications of Academising the HE Sector}

Many education researchers have discussed the various challenges associated with transformation within the higher education sector in South African, including how the various changes influence performance of functions, roles, and responsibilities (Lotz-Sisitka \& Lupele 2015; Maserumule 2005; Raju 2004). Higher education can be viewed as a thick forest of institutions, systems, and practices that do not have clear tracts, values, and goals that connect the institutions and systems to the major challenges of their context (Scholtz 2013). Transformation in higher learning institutions has actually been viewed as a largely top-down process built on a set of predominantly neoliberal and market-driven assumptions, diagnoses, and prescriptions (Scholtz 2013). Very little space has been provided for adequate discussions, debates, and reflections on the identity and role of Universities of Technology in the HEI sector or in broader society. Clarification about how universities of technology differ from traditional universities could assist in establishing the focus and identity of the institutions.

A prominent feature of debates on curriculum transformation is the imperative to move from content-driven to objective-driven and to process- 


\section{Primrose T. Sabela, Mfundo Mandla Masuku \& Lindelani Q. Qwabe}

driven learning, which includes a distinct career-focused and advanced technology education (Lootzt-Sisitka \& Lupele 2015; Maserumule 2005; Scholtz 2013). Before 1994, technikons (now universities of technology) had a strong vocational focus and provided training for a skilled labour force in a range of fields such as engineering (technicians), health, biotechnology, nature conservation, auditing, design, film, video and other pre-professional levels (Garraway \& Winberg 2019; Maserumule 2005; McKenna \& Boughey 2014). These technikons were viewed as institutions of higher learning that offered career-focused, hands-on education and training. They were responsible for producing graduates with knowledge that was immediately relevant in the workplace. While, on the one hand, traditional universities remained repositories of advanced knowledge, technikons, on the other, were responsible for applying knowledge to enable students to perform real-world tasks. Therefore, the distinct focus of Universities of Technology has always been described as providing career focused and advanced technological education through a curriculum focused on experiential and vocational teaching (McKenna 2009; Raju 2005). Their programmes were designed to produce graduates that could readily use their skills in the practical world of work. Furthermore, they closely interacted with work-places. McKenna (2009) posits that the central thrust and purpose of technikons was to provide a broad variety of opportunities that focused on the needs of a developing economy. Similarly, Deissinger and Gonon (2016) view apprenticeship as the cornerstone of economic welfare and associate it with low unemployment rates.

Further, technikons had strong ties with industries and they continually made great efforts to produce competent, employable, and well-prepared graduates for a specific occupation or industry. As alternatives to universities, technikons had lower entry requirements that often made them more inclusive in terms of student admission when compared to traditional universities. Garraway and Winberg (2019) explain that the role of technikons, clear and somewhat unitary, was to produce employees for industry. Academisation of the curriculum has brought terminology such as examinations and progress that far outweigh such phrases as skilled trade and modern apprenticeship, so no equilibrium can be observed between academic and non-academic subjects (Rogers \& Richmond 2016). McKenna (2009) has questioned the rationale behind the higher education sector's commitment to change the status of institutions that were widely recognised and had clearly defined roles and functions. 
The question on whether academisation of former technikons considered the role that these institutions of higher learning had in developing the country's technicians remains relevant. Changing the designation suggests changing the mission and vision as well as the curriculum, which raises questions about whether curricula in Universities of Technology changed, and if so, why and in what ways and for whose benefit were the changes implemented. Further, it was noted that an ill-informed curricula change could be detrimental to the end-product. While it emerged that the curriculum never changed the boundaries between the university-type programmes and extechnikon-type programmes became permeable and fuzzy, which contributed to challenges of articulation (McKenna 2009). The consequences of transformation relate among others to the creation of a series of qualifications, such as Bachelor of Technology (B-Tech), which was added as a compliant measure. The B-Tech qualification has already been phased out because it failed to address issues of articulation and the inherent stigma attached to the name itself (B-Tech) translated to the view that the end product could not be admitted to postgraduate studies in a traditional university because of inadequate grounding in theory. This resulted in traditional universities deciding, apparently at whim, on who to enroll for further studies such a Master's degree after completing a B-Tech degree. Students who held a BTech degree could not be guaranteed a place in a Master's degree programme even in the same school or department. In some instances, admission would be dependent on B-Tech degree graduates successfully completing remedial courses from the Honours programme.

Recently, the Advanced Diploma and Postgraduate Diploma were introduced as a substitute for the B-Tech programme in a bid to address articulation deficiencies and as a compliance strategy to meet admission requirements for the Masters programme in traditional universities. Surprisingly, the Advanced Diploma is not considered a postgraduate qualification and funding bodies such the National Research Foundation (NRF) do not support students enrolled for this programme yet it is a postgraduate diploma qualification. Some Universities of Technology are now abolishing diploma qualifications in order to offer what are known as Bdegrees. In this context, pertinent questions include, but are not limited to these.

1. Why are universities of technology abandoning specialisations that 
previously constituted their strength and relevance to industry?

2. What would be the quality of the 'B-degrees'?

3. How different are entry requirements for 'B-degrees' from those of the diploma qualifications that are being phased out?

We argue that the drive and the urgency of universities of technology to academise could cause more harm than good if the process is not carefully monitored and evaluated. Furthermore, the Master of Technology (M-Tech) and Doctor of Technology (D-Tech) qualifications have also been changed to Master's and Doctor of Philosophy respectively as a form of face lifting and to align the qualifications with HEQSF requirements.

There are mixed responses among scholars regarding this. Garraway and Winberg (2019) posit that the transformation of technikons to universities of technology could be viewed as more of a reputational marketing ploy than a substantive change in identity whereas Maserumule (2005) maintains that the changing of technikons to universities of technology was probably done out of a need to conform to the international trends such as the German Technische Universitäten. Further, changing the designation was viewed as being apparently attractive but superficial and without value. It is critical that implications and challenges that relate to curriculum transformation, functions, and roles of the renamed institutions are duly considered. Maserumule (2005) argues that the changes were not accompanied by a detailed concept document outlining expectations that could guide these institutions. Further, Maserumule (2005) criticises the lack of clarity in having the curriculum changed to intellectualise or academise without regard for subjects that cannot be theorized such as those that have a special focus on practical application. Rogers and Richmond (2016) claim that academisation has differentiated between academic and non-academic subjects with automatic degrading and placing of the latter (drama, art etc.) low down in the hierarchy of curricula value.

Despite the skepticism associated with the academisation of former technikons, McKenna (2009) argues that the decision to change the technikons was taken to extend programmes to enable universities of technology to offer and award undergraduate and postgraduate degrees, arguing that the change will encourage the advancement of applied research for the benefit of the industries served and will adequately address issues of articulation. Rogers and Richmond (2016), however, maintain that programmes currently offered in universities of technology have incorporated a stronger element of theory. This 
change ignores the fact that former technikon programmes exhibited a knowledge base characterised by principles of practice rather than a theoretical component typical of a traditional university. This means that the curriculum offered was instrumental in its approach and students learned skills in a theoretical vacuum (Maserumule 2005). Prior to the transition from technikon to university of technology, lecturers were normally drawn from occupational spheres rather than the academically experienced with research-based higher degrees (Garraway \& Winberg 2019).

Most lecturers in the former technikons were not actively engaged and had no reason to engage in research and the teaching and learning materials that were used for teaching were prepared by lecturers without delving into unearthing the theoretical basis and reasons for practices. However, the curriculum was supposed to be of nationally acceptable standards and was quality assured by the Certification Council for Technikon Education (SERTEC), a quality assurance body responsible for the evaluation of technikon operations and teaching at the time. However, Maserumule (2005), in comparing the process though which published academic books go before being made available to the reading public claims that teaching and learning manuals that were used in former technikons were not subjected to peer review processes by the wider community simply because they were meant only for instructional interaction with students. The system of manual development in technikons denied students the opportunity to engage with many sources related to issues that constituted the core syllabus.

According to Scholtz (2013) transformation of higher education meant two related processes - conceptualising and contextualising the role and functions of former technikons including the academisation of the curriculum within the restructured higher education landscape. She metaphorically uses both chaotic and complexity theory to describe curriculum transformation in universities of technology. The argument presented refers to the development of curricular in these transformed institutions without knowing what the final product should look like. Further, lecturers had no prior experience in curriculum development. Actually, curricula for specific qualifications in technikons were developed by a system of convenor technikons with input from various stakeholders. The process of curriculum development was centrally managed with academic staff expected only to implement them. The renaming of technikons required in-depth evaluation of what was taught, how the programme was structured, how industry was to be roped in, and how to 
embrace a myriad of pedagogical imperatives of programme delivery (Scholtz 2013).

Compounding the above challenges was the super complexity of the nature of curriculum change coupled with the need for universities of technology to deal with internal and external changes while finding ways to establish their identities. Challenges were also experienced with the disorderly nature of curricula revision or review since it was characterised by training sessions that provided an overview without any stipulated format. Garraway and Winberg (2019) claim that most technikons offered undergraduate certificates and diploma programmes not intended to attract the calibre of student willing to pursue postgraduate studies. Similarly, Mckenna (2009) claims that technikons had a history of attracting low calibre students who were incapable of enrolling for postgraduate studies. Further, most of the academic staff did not have capacity to conduct research and supervise at postgraduate level.

Varied views have also been expressed about the capability of technikon staff to review, recurriculate, academise, and restructure the curriculum to respond to the developmental imperatives of the changing world. Several scholars have expressed concern about a number of issues including the shortage of suitably qualified and experienced staff to review, recurriculate, and supervise postgraduate studies and research capacity (Garraway \& Winberg 2019; Maserumule 2005; Scholzt 2013). Scholtz (2013) also noted the disorderly nature of curriculum revisions but maintained that recurriculation became successful when academic members were keen to participate in curriculum review, although indicators on how success could be measured still need to be developed. Other concerns raised relate to the dogmatism, firm conviction, and paternalism that were displayed by professional bodies that previously assisted with the development of technikon curricula and the disconnection between the expectations of employers and departmental management.

\section{Research in Universities of Technology}

The transition from technikons to universities of technology in the context of South Africa's higher education sector has been perceived by some researchers as a marketing ploy (Garraway \& Winberg 2019). Therefore, it is not surprising that academics at universities of technology contribute only 
about a third of the research output when compared to their counterparts in traditional universities (CHE 2019). This difference can be attributed to several factors. Research at traditional universities is mostly driven by postgraduate students as opposed to universities of technology that do not offer many postgraduate programmes which, incidentally, presents a major obstacle to their research productivity. Bozalek and Boughey (2012) describe how higher education institutions were (mis)framed post 1994, which resulted in historically Black institutions and universities of technology being overlooked in terms of research funding in favour of mainly historically White institutions. While these scholars focused on the mis(framing) of higher education institutions, we highlight the struggles of universities of technology to contribute significantly to higher education research output. Further, it explains how funding of higher education institutions is skewed towards research productivity. Thus, Bozalek and Boughey (2012) argue that the funding formula does not distinguish between different categories of institutions nor consider their backgrounds.

Apart from funding constraints and a limited number of postgraduate qualifications, lack of adequately experienced academic researchers also poses serious challenges to research productivity at universities of technology. Consequently, some universities of technology (e.g. Mangosuthu University of Technology in Durban, South Africa) have resorted to recruiting retired academics from traditional universities to help bolster the institution's research activities. This attempt is a recognition and acknowledgement by leaders in such institutions that something must be changed if their research output is to be compared to that of their traditional university counterparts. Such strategies are commendable but are superficial and unsustainable. Universities of technology are teaching-intensive institutions that leave little room for academics who are interested in research to pursue this type of scholarly work. Some have attempted to design workload models that will consider the involvement of academics in research activities. However, the question of whether South Africa's universities of technology are living up to expected standards and are comparable to the traditional university remains. Further, the need to academise these institutions in a manner that is bound to compromise their core business, which is to train students who are vocationally strong and ready for work, remains questionable.

However, the picture painted by the comparison between universities of technology and the traditional university is not as gloomy as it may appear. 
There are universities of technology that have increased their research output in the field of applied sciences through both national and international research collaborations with other researchers (see Chiware \& Skelly 2016). Further, the Universities of Technology research niche areas are linked with industrial needs to ensure that they remain relevant to the potential employers of their respective students. Okafor (2010) attests that the economy and prosperity of the country are somewhat determined by research productivity in areas of applied science. It is acknowledged that Universities of Technology have contributed positively to the economic development of their countries by producing graduates who respond to the needs of the job market. Findings from Chiware and Becker (2018) indicate that the graduates' research skills enable them to identify the problems and needs of both society and industry by finding relevant scientific solutions to those identified problems.

The South African government has established research frameworks to enhance the research agenda of Universities of Technology by increasing their research funding, and by creating specialised research units and research chairs at Universities of Technology. These initiatives were strengthened by the effective recruitment of highly skilled academic staff in research and the development of research infrastructure through sustainable funding of laboratories and research equipment (Schemm 2013; Chiware \& Becker 2018). Academisation of the curriculum should be accompanied by a strong research focus in order to enrich the curriculum with research findings. Considering the challenges associated with universities of technology in the context of research, we argue that research output by these institutions will remain dismal for the foreseeable future. Against this backdrop, questioning whether it was necessary for former technikons to shift from a strong vocational focus to a more academic orientation is imperative (Chiware \& Becker 2018; Schemm 2013).

\section{Conclusion}

Within the context of South Africa, technikons played a specific part in both the higher education sector, and in commerce and industry since they had a particularly distinct focus that made their role very clear. While traditional universities were repositories of advanced knowledge, technikons were responsible for the application of knowledge to carry out tasks in the practical 
or physical work environment. As technikons have shifted to become universities of technology, debates have arisen around the relevance of what is being taught in this new type of HEI, raising questions about whether the title of these institutions have simply changed without any curricula change. Academisation and intellectualisation presumably aim to produce students with critical thinking skills that are relevant to the changing world of work. Academics with up-to-date knowledge and exposure to new trends in knowledge production are required in the academisation of the curricula. However, it is essential for institutions to identify their distinctiveness and institutional culture with a set of norms, values, and beliefs. The roles of both traditional universities and universities of technology should be clearly defined so that each segment of the higher education landscape in the country can fulfil its mandate without overlapping too much on those of others. The culture and identity of these institutions is what defines them and should be preserved at all cost. The framework of higher education should, therefore, be clear in terms of the extent to which universities of technology should academise. If this process is not carefully monitored and evaluated the country runs the risk of experiencing severe skills shortages. The need for work ready graduates who can support and move the nation's economy forward remains legitimate. The Department of Higher Education and Training should consider reviewing the research funding formula to assist universities of technology to grow their research capacity.

\section{References}

Adetiba, T.C. 2019. Massification of Higher Education in South Africa: The Good, the Bad and the Ugly. In Proceedings of International Academic Conferences (No. 9410873). International Institute of Social and Economic Sciences. https://doi.org/10.20472/IAC.2019.050.001 PMid:30809559 PMCid:PMC6374998

Aina, T.A. 2010. Beyond Reforms: The Politics of Higher Education Transformation in Africa. African Studies Review 33, 1: 21-40. https://doi.org/10.1353/arw. 0.0290

Altbach, P.G. 2004. Globalisation and the University: Myths and Realities in an Unequal World. Tertiary Education \& Management 10, 1: 3-25. https://doi.org/10.1080/13583883.2004.9967114 
Altbach, P. \& T. Davis 1999. Global Challenge and National Response: Notes for an International Dialogue on Higher Education in the International Higher Education. Boston: Boston College.

https://doi.org/10.6017/ihe.1999.14.6471

Ahrari, S., B.A. Samah, M.S.H.B. Hassan, N.W.Wahat \& Z. Zaremohzzabieh 2016. Deepening Critical Thinking Skills through Civic Engagement in Malaysian Higher Education. Thinking Skills and Creativity 22: 121-128. https://doi.org/10.1016/j.tsc.2016.09.009

Badat, S. 2010. The Challenges of Transformation in Higher Education and Training Institutions in South Africa. Development Bank of Southern Africa 8: 1-37.

Barnett, R. 1990. The Idea of Higher Education. London: McGraw-Hill Education.

Bozalek, V. \& C. Boughey. 2012. (Mis)framing Higher Education in South Africa. Social Policy \& Administration 46, 6: 688-703.

https://doi.org/10.1111/j.1467-9515.2012.00863.x

Brennan, J., R. King \& Y. Lebeau 2004. The Role of Universities in the Transformation of Societies. Synthesis Report. Centre for Higher Education Research and Information/Association of Commonwealth Universities, $U K$.

Chiware, E. \& L. Skelly. 2016. Publishing Patterns at the Cape Peninsula University of Technology. South African Journal of Science 112, 1/2: 16. https://doi.org/10.17159/sajs.2016/20140220

Chiware, E.R. \& D.A. Becker 2018. Research Trends and Collaborations by Applied Science Researchers in South African Universities of Technology: 2007-2017. The Journal of Academic Librarianship 44, 4: 468-476. https://doi.org/10.1016/j.acalib.2018.05.003

Cranton, P. 2011. A Transformative Perspective on the Scholarship of Teaching and Learning. Higher Education Research \& Development 30, 1: 75-66. https://doi.org/10.1080/07294360.2011.536974

Deissinger, T. \& P. Gonon. 2016. Stakeholders in the German and Swiss Vocational Educational and Training System: Their Role in Innovating Apprenticeships against the Background of Academisation. Education+ Training 58, 6: 568-577. https://doi.org/10.1108/ET-02-2016-0034

Department of Education 1997. Education White Paper 3: A Programme for the Transformation of Higher Education. Government Gazette, 386 (18207). 
Department of Higher Education and Training 2015. National Qualifications Framework Act (67/2008): Revised Policy on the Minimum Requirements for Teacher Education Qualifications. Government Gazette 596 (38487).

Dison, A., M. Walker \& M. Mclean 2008. The Contribution of Higher Education to Transformation, Development and Poverty Reduction: Overview of the South African Higher Education Context. Background Paper, 6. Available at: http://r4d.dfid.gov.uk/Output/179325.

(Accessed on 10 March 2020.)

Ek, A.C., M. Ideland, S. Jönsson \& C. Malmberg 2013. The Tension between Marketisation and Academisation in Higher Education. Studies in Higher Education 38, 9: 1305-1318.

https://doi.org/10.1080/03075079.2011.619656

Garraway, J. \& C. Winberg. 2019. Reimagining Futures of Universities of Technology. Critical Studies in Teaching and Learning 7, 1: 38-60.

Habib, A., S. Morrow \& L. Bentley. 2008. Academic Freedom, Institutional Autonomy and the Corporatised University in Contemporary South Africa. Social Dynamics 34, 2: 140-155.

https://doi.org/10.1080/02533950802280022

Hey, V. \& L. Morley. 2011. Imagining the University of the Future: Eyes Wide Open? Expanding the Imaginary through Critical and Feminist Ruminations in and on the University. Contemporary Social Science 6, 2: 165-174. https://doi.org/10.1080/21582041.2011.580618

Kreber, C. 2006. Developing the Scholarship of Teaching through Transformative Learning. Journal of Scholarship of Teaching and Learning 6, 1: 88-109.

Kyvik, S. 2008. The Dynamics of Change in Higher Education: Expansion and Contraction in an Organisational Field (27). Dordrecht: Springer Science $\&$ Business Media.

Lategan, L.O.K. 2008. A Conceptual Analysis of a University of Technology and its Contribution to Research and Development. Interdisciplinary Journal 7, 2: 61-78.

Lategan, L.O.K. 2009. The University as Key Concept in Higher Education Studies. In Bitzer, E. (ed.). Higher Education in South Africa: A Scholarly Look behind the Scenes. Stellenbosch: African Sun Media. https://doi.org/10.18820/9781920338183/03

Lotz-Sisitka, H. \& J. Lupele 2015. Curriculum Transformation in Higher 
Primrose T. Sabela, Mfundo Mandla Masuku \& Lindelani Q. Qwabe

Education Institutions: Some Perspectives from Africa. Drivers and Barriers for Implementing Sustainable Development in Higher Education 49.

Maassen, P. \& N. Cloete. 2006. Global Reform Trends in Higher Education. In Transformation in Higher Education. Dordrecht: Springer

Maserumule, M.H. 2005. Designating Technikons Universities of Technology in South Africa: Implications for Public Management Education. African Journal of Public Administration and Management 16, 1:14-27.

McEwen, C. \& F. Trede. 2014. The Academisation of Emerging Professions: Implications for Universities, Academics and Students. Power and Education 6, 2: 145-154. https://doi.org/10.2304/power.2014.6.2.145

McKenna, S. 2009. 'Only a Name Change': The Move from Technikon to University of Technology. The Journal of Independent Teaching and Learning 4, 1: 37-48. https://doi.org/10.1080/13562517.2014.934351

McKenna, S. \& C. Boughey. 2014. Argumentative and Trustworthy Scholars: The Construction of Academic Staff Research-intensive Universities. Teaching in Higher Education 19, 7: 825-834.

Ndlovu-Gatsheni, S.J. 2017. The Emergence and Trajectories of Struggles for an 'African University': The Case of Unfinished Business of African Epistemic Decolonisation. Kronos 43,1: 51-77. https://doi.org/10.17159/2309-9585/2017/v43a4

Okafor, V.N. 2010. Analysis of Research Output of Academics in Science and Engineering in Southern Nigerian Universities: An Imperative Study. South African Journal of Libraries and Information Science 76, 21: 81190.

Raju, J. 2004. The Historical Evolution of University and Technikon Education and Training in South Africa: Implications for Articulation of LIS Programmes. Innovation 29, 1:1-12.

https://doi.org/10.4314/innovation.v29i1.26489

Republic of South Africa. Advanced Technical Education Act. Act 40 of 1967.

Pretoria: Government Printers,

Republic of South Africa. Advanced Technical Education Act. Act 43 of 1979.

Pretoria: Government Printers.

Republic of South Africa 1996. The Constitution of the Republic of South Africa Act 108 of 1996: Pretoria: Government Printers.

Republic of South Africa. 1997. The Higher Education Act. Act 101 of 1997. Pretoria: Government Printers. 
Rogers, G. \& K. Richmond. 2016. Fair Work and Productivity. Fraser of Allander Economic Commentary 40, 3: 51-62.

Schemm, Y. 2013. Africa Doubles Research Output over Past Decade, Moves towards a Knowledge-based Economy. Research Trends 35: 11-12.

Scholtz, D. 2013. Curriculum Revision: Challenges in Responding to Change. Progressio 35, 3: 132-152.

Scott, P. 2019. Martin Trow's Elite-Mass-Universal Triptych: Conceptualising Higher Education Development. Higher Education Quarterly 73,4: 496506. https://doi.org/10.1111/hequ.12224

Scott, J.W. 2019. Knowledge, Power, and Academic Freedom. New York: Columbia University Press. https://doi.org/10.7312/scot19046

Waghid, Y., S. Berkhout, D. Taylor \& J. de Klerk. 2005. In Defence of Institutional Autonomy and Academic Freedom: Contesting State Regulation of Higher Education. South African Journal for Higher Education 19,6: 1117-1195. https://doi.org/10.4314/sajhe.v19i6.25553

Primrose T. Sabela Senior lecturer School of Development Studies University of Mpumalanga Nelspruit Thandeka.Sabela@ump.ac.za

Mfundo Mandla Masuku Senior lecturer School of Development Studies University of Mpumalanga Nelspruit Mandla.Masuku@ump.ac.za

Lindelani Q. Qwabe Senior lecturer Department of Chemistry Mangosuthu University of Technology Umlazi lqwabe@mut.ac.za 